\title{
Chromosomal abnormalities in recurrent miscarriages by conventional karyotyping analysis
}

Alessandra Bernadete Trovó de Marqui 1

1 Departamento de Patologia, Genética e Evolução. Instituto de Ciências Biológicas e Naturais. Universidade Federal do Triângulo Mineiro. Campus I.
Praça Manoel Terra, n 330. Uberaba, MG, Brasil. CEP: 38015-050. E-mail: alessandratrovo@hotmail.com

\begin{abstract}
Objectives: to describe the prevalence and types of chromosomal abnormalities in couples with recurrent miscarriage and products of conception.

Methods: electronic searches were performed in the PubMed/Medline database and in the Portal Regional da Biblioteca Virtual em Saude/BVS (Regional Website of the Virtual Library in Health/BVS) using the descriptors "chromosomal abnormalities and abortions and prevalence". After applying the inclusion and exclusion criterias, 17 studies were selected.

Results: 11 studies were conducted in couples with recurrent miscarriage and six in products of conception. The main results of the couples with recurrent miscarriage were: the frequency of chromosomal abnormalities which varied from $1.23 \%$ to $12 \%$ and there was a predominance alteration of the chromosomal structures (reciprocal translocations, followed by Robertsonian). In products of conception, the results observed were: the frequency of chromosomal abnormality was above 50\% in approximately $70 \%$ of the studies; there was a predominance alteration of the numerical chromosomal (trisomy - chromosomes 16, 18, 21 and 22, followed by polyploidy and monosomy X).

Conclusions: in summary, cytogenetic alterations represent an importante cause of pregnancy loss and its detection can help couples with genetic counseling. Therefore, the value of knowledge on the prevalence of cytogenetic abnormalities in miscarriage samples is unquestionable, once it is permitted a proper genetic counseling for the couple.

Key words Miscarriage, Chromosome abnormalities, Cytogenetics, Genetic translocation, Genetic counseling
\end{abstract}




\section{Introduction}

Recurrent miscarriage (RM), also referred to as recurrent pregnancy loss (RPL) or habitual abortion (HA), is classically defined by Royal College of Obstetricians and Gynaecologists (RCOG) as the occurrence of three or more consecutive abortions prior to 20 weeks of gestation. 1 However, the American Society of Reproductive Medicine (ASRM) has recently redefined recurrent pregnancy loss as two or more abortions. 2,3

The RM etiology may be multifactorial and about $40-60 \%$ of these patients are non-identifiable causes, in this case the condition is classified as idiopathic or unexplained RM.4,5

The main etiological factors related to RM are: 1) genetic abnormalities (parental chromosomal rearrangements and abnormal embryonic karyotypes); 2) endocrine abnormalities; 3 ) anatomical factors; 4) immune factors; 5) inherited thrombophilic disorders; 6) infective agents; 7) miscellaneous factors (lifestyle and environmental factors); and 8) new risk factors. $6-8$

A recent study described women with RM epidemiologic and obstetric characteristics and some risk factors were identified such as advanced age, consumption of alcoholic beverages and higher body mass index. ${ }^{9}$ In this sense, lifestyle modifications should also be implemented to improve reproductive prognosis. 7

Genetic factors, mainly chromosomal abnormalities, are the most common cause of early miscarriage $(50-60 \%)$. The chromosomal abnormalities can be divided in two basic groups: numerical and structural abnormalities. These abnormalities can involve one or more autosomal chromosomes, sexual chromosomes and both simultaneously and are identified by using the conventional cytogenetic methods based on light microscopy. 4,5

Conventional karyotyping is traditionally performed to elucidate the possible causes of fetal loss, indicanting if any chromosomal abnormality was responsible for the miscarriage. The use of the classic cytogenetic to assess the fetal karyotype of the miscarriage material is complicated because the sample may be contaminated by the maternal tissue and the associated risk of false negative results. ${ }^{10} \mathrm{In}$ addition, products of conception are characterized by a low sample quality that often leads to a cell culture failure.11,12 In case of culture failure or maternal contamination, molecular techniques may contribute to detect additional chromosome abnormalities in these miscarriage samples in addition to standard karyotyping. 13
A recent review also summarized a current knowledge on the genetic causes (karyotype abnormalities, recessive diseases carrier status, dominant diseases and thrombophilia) of the RM.10 Genetic reasons may involve changes in the genetic embryonic/fetal or parental material. Therefore, genetic tests may be performed in both parents as well as in the miscarriage material (fetus or afterbirth). 10

The presence of karyotype abnormalities in one of the parents is one of the most common known causes of RM. They are most commonly found as balanced rearrangements, i.e. abnormalities cause no clinical symptoms in carriers but possibly induce the production of abnormal reproductive cells containing abnormal amounts of genetic material.10 In couples with RM, one partner - frequently is the woman - will have a genetically balanced structural chromosome rearranged being the most common balanced translocation (reciprocal followed by Robertsonian). The inversions are much rarer but are also associated to an increased risk of RM. 6

In products of conception, at least $50 \%$ of all miscarriages are associated to numerical chromosome abnormalities - trisomy, polyploidy and monosomy X. 6 Therefore, genetic counselling is important when a genetic factor is identified. 6

Others genetic factors, such as genetic polymorphisms may contribute for RM.4,5 A recent systematic review and meta-analysis showed significant associations among RM and 53 genetic polymorphisms of 37 genes. The genetic variants of $H L A-G$, IFNG, TNF, IL-6, IL-10, FII, FV, FXIII, ITGB3, MTR, MTHFR, PAI-1, NOS3, KDR, TP53, VEGFA, CYP17, CYP1A1, CYP2D6, ANXA5, and XCI may serve as RM biological markers. 14 These genetic variants were associated to the immune response, thrombophilia, placental function and hormonal and detoxification system and may contribute to the RM pathogenesis. ${ }^{15}$ Although significant associations have been found among many genetic variants and $\mathrm{RM}$, further functional research is needed to establish its role as biomarkers and introduce it into a clinical practice routine. 15

$\mathrm{RM}$ is an important reproductive health issue. Despite various etiologies have been identified, almost half of the cases remain unexplained. Regardless of the cause, a thorough follow-up with an important psychological support can help most couples achieve a successful birth. ${ }^{7}$

Faced with this, the objectives of this present study were to describe the prevalence and types of chromosomal abnormalities in couples with RMs and products of conception. 


\section{Methods}

Electronic searches were performed in PubMed/Medline database (available at http://www.ncbi.nlm.nih.gov/pubmed) and in the Portal Regional da Biblioteca Virtual em Saúde/BVS (Regional Website of the Virtual Library in Health/BVS) (available at bvsalud.org), in June, 2017. What the descriptors used in both searches were: "chromosomal abnormalities and abortions and prevalence". The steps on the electronic search are presented in Figure 1.
The initial screening of the publications was based on the analyses of the titles and/or abstracts. The inclusion criteria were: research articles closely related to the objectives of this research, which used conventional cytogenetic techniques; those published in the last 10 years (that is, between 2007 and 2016), in English, Portuguese and Spanish, which were full text, entirely available and free of charge. The articles that did not fulfill the previous established criteria were excluded.

Conventional karyotyping is defined as the morphological characterization of an individual's

Figure 1

Flow chart illustrating the steps on the electronic search.

IDENTIFICATION

TRACKING

EXCLUSION
Publications in the database identified by electronic search

PubMed / Medline $(n=102)$

BVS $(n=137)$

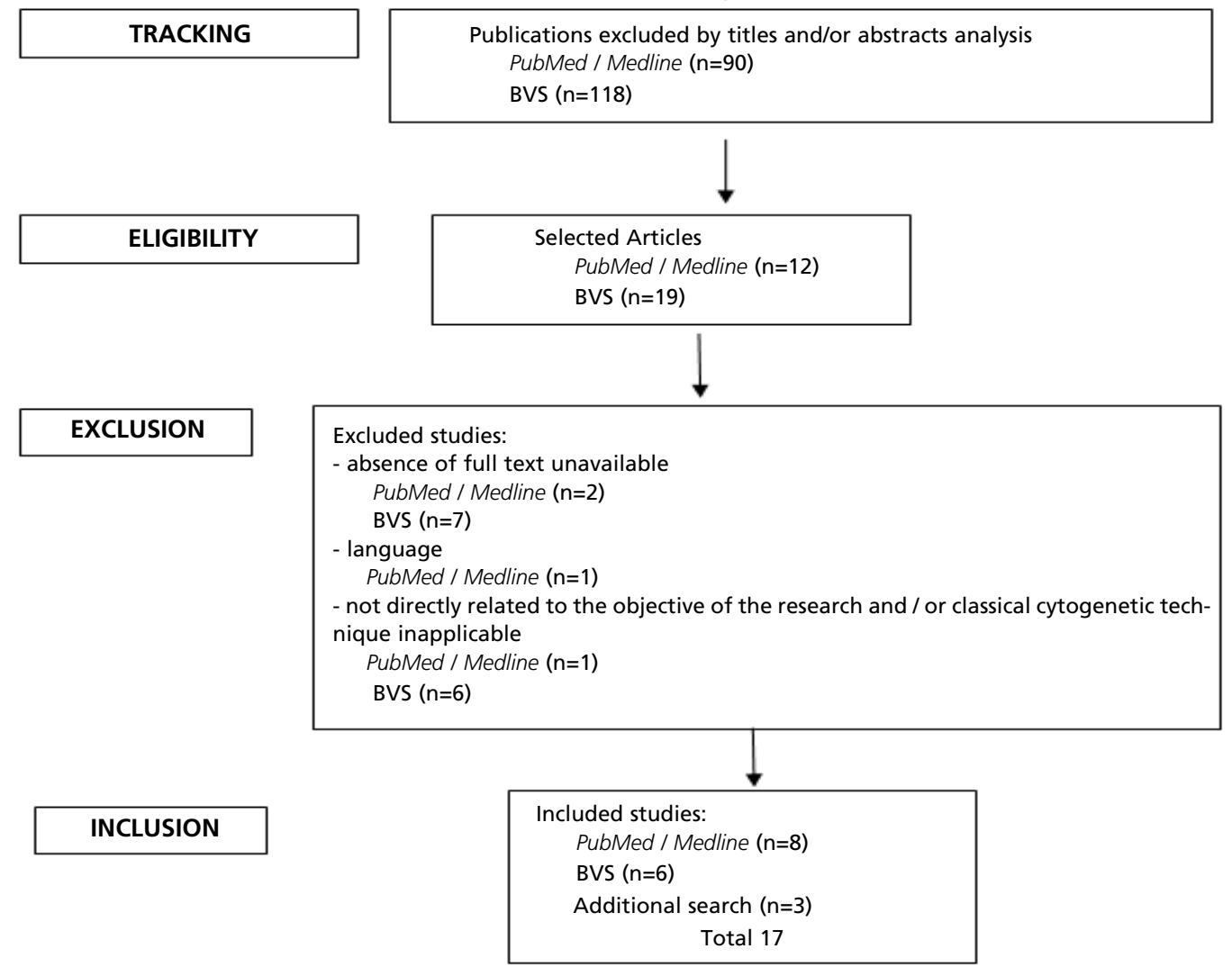


complement chromosomal, including number, form and size of the chromosomes. It can detect abnormalities in the entire genome and therefore is used as a standard to detect chromosome abnormalities in miscarriages samples. ${ }^{13}$

From the 102 and 137 articles identified in PubMed / Medline and BVS, eight and six were included, respectively. A further search was performed from the references of the articles identified in the investigated database and three articles $11,12,16$ were included, a total of 17 scientific articles.

\section{Results}

From the 17 articles included in this literature review, 11 were carried out in couples with RM (Table 1) and six in products of conception (Table 2 ). The frequencies and types of chromosomal abnormalities in couples with RM and miscarriage material are shown in Tables 1 and 2, respectively.

Some studies have shown higher prevalence of chromosomal abnormalities in couples with larger number of miscarriages. 16,18 According to Ghazaey et al. 16 the highest percentage of chromosomal abnormalities was observed in couples with five or more RMs (4.7\% - 1 RM, $11 \%$ - 2 RMs, $15 \%$ - 3 RMs, $15 \%-4$ RMs and $21.2 \%-\geq 5$ RMs). Another study showed that chromosome abnormalities were found in $5 \%$ of the couples with a history of two miscarriages, in $10.3 \%$ with three miscarriages and in $14.3 \%$ with four or more miscarriages. 18

Table 1

Types and prevalence of chromosomal abnormalities in couples with RM.

\begin{tabular}{|c|c|c|c|}
\hline Study & Sample & Types of chromosomal abnormalities & Prevalence \\
\hline Ozawa et al. 17 & $\begin{array}{l}2324 \text { couples } \\
\text { had a history } \\
\text { of two or } \\
\text { more conse- } \\
\text { cutive preg- } \\
\text { nancy loss }\end{array}$ & $\begin{array}{l}\text { chromosome abnormalities: } 114 \text { couples } \\
3.18 \%(74) \text { reciprocal translocations, } 0.99 \%(23) \text { Robertsonian translocations ( } 17 \\
\text { women, } 0.73 \% \text { and } 6 \text { men } 0.26 \%), 0.43 \%(10) \text { inversions and } 0.39 \% \text { (9) others } 14 \\
\text { couples with normal variants }(0.6 \%) \text { and } 81 \text { with pericentric inversion } 9(3.49 \%)\end{array}$ & $4.91 \%$ \\
\hline Kiss et al.18 & $\begin{array}{l}108 \text { couples } \\
\text { with history } \\
\text { of two or } \\
\text { more RMs }\end{array}$ & $\begin{array}{l}\text { chromosome abnormalities: } 10 \text { cases ( } 5 \text { women and } 5 \text { men) woman-man ratio } 1: 1 \\
\text { chromosomal analysis (normal results): } 46, X X(n=100) \text { and } 46, X Y(n=103) \\
5 \text { structural alterations ( } 30 \% \text { of reciprocal translocation, } 20 \% \text { of Robertsonian } \\
\text { translocation, } 10 \% \text { of chromosome inversion) and } 5 \text { numerical alterations ( } 50 \% \\
\text { of mosaicism - sexual chromosomes) } \\
\text { in one of the couples, the woman presented two concomitant alterations } \\
3 \text { polymorphisms }(1.4 \%)\end{array}$ & $9.3 \%$ \\
\hline Pal et al. 19 & $\begin{array}{l}56 \text { couples } \\
\text { who had two } \\
\text { or more mis- } \\
\text { carriages }\end{array}$ & $\begin{array}{l}\text { five couples - chromosomal abnormality in one partner } \\
4 \text { cases - structural alterations ( } 60 \% \text { reciprocal translocations - women and } 20 \% \\
\text { Robertsonian D/D translocations - men) } \\
1 \text { case - numerical abnormality ( } 20 \% \text { mosaic of Down syndrome - men) } \\
60 \%(n=3) \text { occurred in women and } 40 \%(n=2) \text { in men } \\
\text { woman-man ratio } 1.5: 1\end{array}$ & $8.9 \%$ \\
\hline
\end{tabular}

RMs: recurrent miscarriages. 
Types and prevalence of chromosomal abnormalities in couples with RM.

\begin{tabular}{|c|c|c|c|}
\hline Study & Sample & Types of chromosomal abnormalities & Prevalence \\
\hline Dutta et al.20 & $\begin{array}{l}1162 \text { couples } \\
\text { with recur- } \\
\text { rent miscar- } \\
\text { riages }\end{array}$ & $\begin{array}{l}\text { chromosomal anomalies: } 78 \text { cases } \\
1.41 \%(33) \text { structural abnormalities [more frequent: } 21 \text { cases of balanced } \\
\text { reciprocal translocations and } 6 \text { cases of Robertsonian translocations) - } \\
\text { women ( } 18 \text { cases) and men ( } 9 \text { cases)] } \\
1.89 \% \text { (44) polymorphic variants (chromosome } 9 \text { ) } \\
0.05 \% \text { (1) numerical anomaly (mosaic } X Y / X X Y \text { ) }\end{array}$ & $3.35 \%$ \\
\hline Niroumanesh et al.21 & $\begin{array}{l}100 \text { couples } \\
\text { with two or } \\
\text { more miscar- } \\
\text { riages }\end{array}$ & $\begin{array}{l}\text { chromosome abnormalities: } 13 \text { cases } \\
\text { chromosomal abnormalities: } 8 \% \text { women and } 5 \% \text { men } \\
\text { woman-man ratio } 1.6 / 1 \\
4(30.8 \%) \text { balanced reciprocal translocations } \\
3(23 \%) \text { Robertsonian translocations ( } D \text { and } G \text { groups) } \\
3(23 \%) \text { pericentric inversions (chromosomes } 7 \text { and } 9) \\
1(7.7 \%) \text { paracentric inversion (chromosome } 16) \\
1(7.7 \%) \text { chromosomal marker } \\
1(7.7 \%) \text { polymorphism } 9 q h+\text { (woman who had a history of eight } \\
\text { miscarriages and one live birth) } \\
\text { inv(9) - one couple with a similar chromosomal abnormality }\end{array}$ & $12 \%$ \\
\hline Saxena et al.22 & $\begin{array}{l}955 \text { couples } \\
\text { with recur- } \\
\text { rent preg- } \\
\text { nancy loss }\end{array}$ & $\begin{array}{l}\text { chromosomal abnormalities: } 49 \text { cases } \\
63.3 \% \text { (31) reciprocal translocations ( } 18 \text { women and } 13 \text { men), } 20.4 \% \text { (10) } \\
\text { Robertsonian translocations ( } 7 \text { women and } 3 \text { men), } 10.2 \% \text { (5) inversions, } \\
2.04 \% \text { (1) derivative chromosome, } 2.04 \% \text { (1) aneuploidy sexual chromosome, } \\
2.04 \% \text { (1) marker chromosome }\end{array}$ & $1.23 \%$ \\
\hline Gonçalves et al.23 & $\begin{array}{l}151 \text { women } \\
\text { and } 94 \text { part- } \\
\text { ners (couples } \\
\text { with two or } \\
\text { more recur- } \\
\text { rent first } \\
\text { trim e st er } \\
\text { miscarriages) }\end{array}$ & $\begin{array}{l}\text { chromosome abnormalities: } 13 \text { cases ( } 11 \text { women and } 2 \text { partners) } \\
\text { women: } 4.7 \% \text { X-chromosome mosaicism }(n=7), 2 \% \text { reciprocal translocations } \\
(n=3) \text { and } 0.6 \% \text { Robertsonian translocations }(n=1) \\
\text { men: } 1 \% \text { X-chromosome mosaicism }(n=1) \text { and } 1 \% \text { inversions }(n=1) \\
3.65 \% \text { structural alterations }(n=5) \text { and } 5.75 \% \text { numerical alterations }(n=8) \\
\text { normal variations in the chromosomes structure: } 4.6 \% \text { (women, } n=7) \text { and } \\
6.4 \% \text { (men, } n=6) \text {, more frequent: } 9 q h+(9 \text { cases) }\end{array}$ & $\begin{array}{c}7.3 \% \text { (woman) } \\
2.1 \% \text { (man) }\end{array}$ \\
\hline Karatas et al. 24 & $\begin{array}{l}142 \text { couples } \\
\text { with recur- } \\
\text { rent miscar- } \\
\text { riage ( } \geq 2 \text { pre- } \\
\text { gnancy loss } \\
\text { that occurred } \\
\text { before the } \\
\text { 20th gesta- } \\
\text { tional week) }\end{array}$ & $\begin{array}{l}\text { chromosome abnormalities: } 33 \text { cases ( } 14 \text { women and } 19 \text { men) } \\
\text { woman-man ratio } 0.7: 1 \\
\text { chromosomal analysis (normal results): } 46, X X(n=128) \text { and } 46, X Y(n=123) \\
\text { women: } 9 \text { polymorphisms }(64.3 \%), 3 \text { translocations }(21.4 \%) \text { and } 2 \text { trisomy } \\
X(14.3 \%) \\
\text { men: } 19 \text { polymorphisms }(100 \%) \\
28 \text { polymorphisms: more frequent } 1 q h+(n=9), 9 q h+(n=4) \text { and } 16 q h+(n=3)\end{array}$ & $\begin{array}{c}9.86 \% \text { (woman) } \\
13.4 \% \text { (man) }\end{array}$ \\
\hline
\end{tabular}


Types and prevalence of chromosomal abnormalities in couples with RM.

\begin{tabular}{|c|c|c|c|}
\hline Study & Sample & Types of chromosomal abnormalities & Prevalence \\
\hline Ghazaey et al. 16 & $\begin{array}{l}728 \text { couples } \\
\text { with history } \\
\text { of miscarria- } \\
\text { ges ranging } \\
\text { from } 1-7\end{array}$ & $\begin{array}{l}\text { chromosomal abnormalities: } 85 \text { ( } 48 \text { women and } 37 \text { men) } \\
\text { woman-man ratio 1.3:1 } \\
43.5 \% \text { (37) reciprocal translocations ( } 24 \text { women and } 13 \text { men) } \\
9.4 \% \text { (8) Robertsonian translocations ( } 4 \text { women and } 4 \text { men) } \\
8.3 \% \text { (7) inversions } \\
8.3 \% \text { (7) numerical abnormalities } \\
52 \text { structural and } 7 \text { numerical abnormalities } \\
30.5 \% \text { (26) polymorphic variants }\end{array}$ & $11.7 \%$ \\
\hline Fan et al.25 & $\begin{array}{l}1948 \text { couples } \\
\text { with two or } \\
\text { more recur- } \\
\text { rent miscar- } \\
\text { riages }\end{array}$ & $\begin{array}{l}\text { chromosomal abnormalities: } 58 \text { cases }(20 \text { men }-34.5 \% \text { and } 38 \text { women - } \\
65.5 \% \text { ) } \\
\text { women-men carriers ratio - approximately } 2: 1 \\
\text { types of structural chromosomal alterations: } 72.4 \%(n=42) \text { reciprocal } \\
\text { translocations, } 19 \%(n=11) \text { Robertsonian translocations and } 8.6 \%(n=5) \\
\text { pericentric inversions } \\
42 \text { reciprocal translocations ( } 15 \text { men }-35.7 \% \text { and } 27 \text { women }-64.3 \% \\
11 \text { Robertsonian translocations ( } 3 \text { men }-27.3 \% \text { and } 8 \text { women }-72.3 \%) \\
5 \text { inversions ( } 2 \text { men }-40 \% \text { and } 3 \text { women }-60 \% \text { ) }\end{array}$ & $\begin{array}{l}2.98 \% \text { (structural } \\
\text { chromosomal } \\
\text { alterations) } \\
(1.95 \% \text { woman } \\
\text { and } 1.03 \% \text { man) }\end{array}$ \\
\hline Sudhir et al. 26 & $\begin{array}{l}440 \text { couples } \\
\text { with at least } \\
\text { two conse- } \\
\text { cutive mis- } \\
\text { carriages }\end{array}$ & $\begin{array}{l}\text { chromosomal abnormalities: } 15 \text { cases } \\
53.3 \%(8) \text { reciprocal translocations, } 6.7 \% \text { (1) Robertsonian translocation, } \\
20 \%(3) \text { duplications and inversion and } 20 \% \text { (3) polymorphic variants } \\
\text { percentage of cases carrying translocations: } 78 \% \text { men and } 22 \% \text { women } \\
\text { (man: woman ratio } 1.5: 1 \text { ) }\end{array}$ & $3.41 \%$ \\
\hline
\end{tabular}

RMs: recurrent miscarriages. 
Table 2

Types and prevalence of chromosomal abnormalities in products of conception.

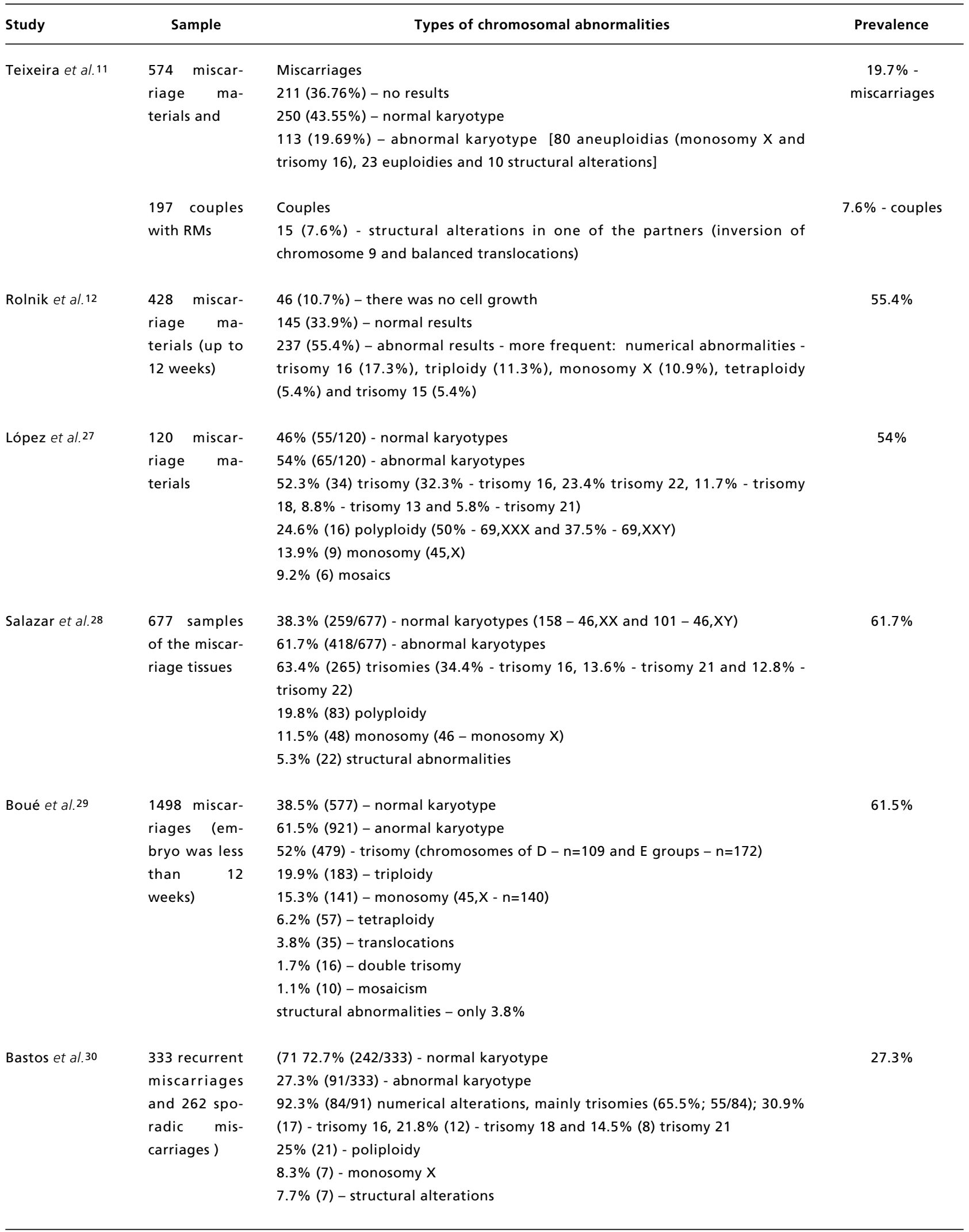

RMs: recurrent miscarriages. 


\section{Discussion}

RM continues to be a challenging reproductive problem for the patient and clinician. It is a traumatic event for couples and has psychological implications, primarily depression and anxiety, and interferes in the couples' relationship. ${ }^{31-33}$ Identifying a cytogenetic cause for a miscarriage can be psychologically important to overcome grief and loss, as well as to decide whether or not to try again. 34

All the studies included in this review employed the karyotype test, which is the most common technique of conventional cytogenetics. It is laborious technique and requires cell culture and the results can take 10 to 15 days. However, it can detect different types of chromosomal abnormalities. In couples with recurrent miscarriage, a lymphocyte culture was carried out from the peripheral blood, with analyses of approximately 20 to 30 metaphases. In case of miscarriage material, the tissue culture (chorionic villus) is used.

The frequency of chromosomal abnormalities among couples with RMs varied from $1.23 \%$ to $12 \%$ (Table 1). The results in this present study are similar to those conducted previously (Table 3 ).

There was a predominance of structural chromosomal abnormalities in couples with recurrent miscarriage. 16,17,19-22,24-26 These findings were in accordance with the literature.34,35,40-44 Only in two studies had higher frequency of numerical chromosomal alterations 23 or the same percentage of numerical and structural alterations. 18

Regarding to the type of the structural alteration, the most frequent ones were the reciprocal translocations, followed by the Robertsonians 16-23,25,26 as reported in the literature (Azim et al. $35-1.6 \%$ reciprocal translocations versus $0.6 \%$ Robertsonian translocations; Kochhar \& Ghosh $42-5.9 \%$ reciprocal translocations versus $0.7 \%$ Robertsonian translocations; Sheth et al. $43-24.7 \%$ reciprocal translocations versus $17.64 \%$ Robertsonian translocations). In the reciprocal translocation there is an exchange of two terminal segments from different chromosomes. Robertsonian translocation involves two acrocentric chromosomes with the loss of short arms and their fusion by or near the centromere. Both reciprocal and Robertsonian translocations are balanced rearrangements, that is, individuals with these translocations do not present phenotypic alterations resulting from them. The existing risks are restricted to the offspring, because, depending on the segregation occurred during the gametogenesis there may be chromosomally unbalanced fetuses formation, consequently non-viable. 18 The translocations were more common in women compared to men. $16,17,19,20,22-25$ The incidence of translocation is more in women than in men according to the literature. 42,43 Only one study showed that the percentagem of men $(78 \%)$ carrying translocations was higher than in women (22\%). 26 Therefore, the genetic counseling for couples with structural chromosomal abnormalities should consider the gender of the carriers. ${ }^{25}$ According to some authors, as men translocations carriers demonstrate reduced fertility. ${ }^{47,48}$ A possible explanation for this difference is that the chromosomal abnormalities such as in men carriers of autosomal reciprocal translocations may cause severe meiotic disorders and stoppage of spermatogenic, but the oogenesis usually is conserved and results in production of gametes with a high risk of presenting unbalanced chromosomal abnormalities. 47,48

It is worth mentioning that most of the studies in Table 1 included the frequency of chromosomal abnormalities of those alterations considered variants of normality (polymorphisms). 16-18,20,21,23,24,26 The frequency of polymorphisms ranged from $0.6 \% 17$ to $100 \% 24$ (Table 1 ). However, some research has shown a possible association between polymorphic variants and infertility. $49-51 \mathrm{~A}$ recent study showed an increase in the frequency of polymorphic variants among infertile patients $(19.4 \%$ in the study group vs. $13.4 \%$ in the control group; $p<$ $0.01) .51$

Of the 17 studies included in this review, only six have assessed miscarriage material (Table 2). Two of them referred not having reached the results and the cell culture failure in the cytogenetic analysis (CA). 11,12 The CA of products of conception presents at least two main challenges, cell culture failure and excess of normal woman karyotypes related to maternal cell contamination. Although the CA of abortive material is highly recommended, alternative complementary techniques for $\mathrm{CA}$ such as Fluorescence in situ Hybridization / FISH,52,53 Multiplex Ligationdependent Probe Amplification / MLPA,54 Quantitative fluorescent polymerase chain reaction / QF-PCR 55,56 and array Comparative Genomic Hybridization / $\mathrm{CGH}^{57}$ have been used for genetic testing on miscarriage samples. These techniques do not require cell culture and have been proposed to optimize the genetic results in unsuccessful karyotype. A comparison of classic cytogenetics, molecular cytogenetics, and molecular biology techniques used for the examination of embryonic / fetal material is presented in two reviews, together with the advantages and disadvantages. 10,13 
Frequencies of chromosomal abnormalities in previous studies.

\begin{tabular}{lcc}
\hline Authors & Number of couples & Frequency of chromosomal abnormalities \% \\
\hline Azim et al.35 & 300 & 5.3 \\
Rao et al.36 & 160 & 11.25 \\
Celep et al.34 & 645 & 3.86 \\
Elgehzal et al.37 & 1400 & 6.93 \\
Yuce et al.38 & 421 & 3.68 \\
Meza-Espinoza et al.39 & 542 & 5.7 \\
Goud et al.40 & 380 & 6.84 \\
El Dahtory et al.41 & 73 & 6.1 \\
Kochhar \& Ghosh42 & 788 individuals (including 367 couples) & 6.8 \\
Sheth et al.43 & 61 & 3.5 \\
Alaraji44 & 7959 individuals (2428 couples and three single mothers) & 9.83 \\
Flynn et al.45 & 171 & 3.52 \\
Turki et al.46 & & 6.43 \\
\hline
\end{tabular}

When the cytogenetic studies are successful, the newer techniques may have limited additional clinical use. However, when the tissue culture fails, the molecular techniques are very useful, although it is important to understand the limitations of each tool. In this manner, a combined approach using conventional and molecular methods will elucidate the cause of the miscarriage on almost all the samples. In a clinical setting this would be optimum. 58

Chromosomal abnormalities in miscarriage material was found above $50 \%$ in approximately $70 \%$ of the studies. $12,27-29$ A frequency of $61 \%$ of chromosome abnormalities in products of conception was detected by CA. 55 Other studies using cytogenetics found lower frequencies (33.24\% and 48\%) of chromosomal abnormalities. 56,59

Two studies published in 2014 and 2017 employed CA and QF-PCR. 55,56 The first applied CA on 534 miscarriages, $73 \%(390 / 534)$ of them was successful. One hundred and forty-four miscarriages $(27 \%, 144 / 534)$ did not grow in culture. A total of 27 cases were analysed by QF-PCR for chromosomes $13,18,21, \mathrm{X}$ and $\mathrm{Y}$ and $30 \%$ (8 of 27 cases) showed a numerical chromosome abnormality by QF-PCR. Two hundred and thirty-seven cases $(61 \%, 237 / 390)$ presented chromosomally alterated by CA. 55 The other was conducted in 884 products of conception, 204 of which were analyzed by cytogenetics and 680 by molecular biology based on QF-PCR. ${ }^{56}$ Despite using different techniques, the abnormal results were similar $(40 \%$ by QF-PCR and $48 \%$ by cytogenetics). 56 A recent study, using only conven- tional CA, with 457 products of conception showed that 382 cases were sucessfully karyotyped while 75 cases of cell culture failed (culture failure rate: $16.42 \%)$. Cytogenetic abnormalities were detected in 127 of the 382 cases $(33.24 \%) .59$

Unlike the findings presented in Table 1, there was a predominance of numerical chromosomal alterations in the studies about miscarriage material. The frequency of numerical chromosomal alterations was higher than $92 \%, 28-30$ reaching $100 \% 27$ in four of the six studies presented in Table 2. On the other hand, the frequency of structural alterations was lower and ranged from $3.8 \%$ to $7.7 \% .28-30 \mathrm{In}$ all the studies in Table 2, the structural chromosomal abnormalities were little frequent in products of conception according to the literature. $.55,59$ When a structural chromosomal alteration is found in the miscarriage material, the karyotype of both parents should be done, in order to assess the inherited nature or the abnormality found in the pregnancy loss. 30

In general, the trisomy was the most common chromosome abnormality detected in the miscarriage material, followed by polyploidy and monosomy X.12,27-30 The most frequent trisomy was the 16 $11,12,27,28,30$ and others trisomies, especially those involving chromosomes 18,21 and 22 are also implicated in the miscarriage. $27,28,30$ Autosomal trisomies were the predominant chromosomal abnormalities with a frequency of $48.8 \%$ (trisomy $16-$ $12.6 \%$; trisomy $22-7.9 \%$; trisomy $21-5.5 \%$; trisomy $13-3.1 \%$; trisomy $10-3.1 \%$ ), followed by 
poliploidy (18.9\% - triploidy and tetraploidy) and 45 , X (16.5\%). Structural chromossomal abnormalities were rare (9.5\%). 59 Trisomy was also the most common chromosome abnormality detected in the miscarriage material, accounting for $63 \%$ (232 of $368)$, followed by polyploidy $(18.8 \% ; 69$ of 368$)$ and monosomy $X(16.6 \%$; 61 of 368$) .56$ The most frequent trisomy was the $16(17.4 \%)$, followed by trisomy $22(17.1 \%) .56$ Another study 55 showed that: (1) trisomy was the most common chromosome abnormality and accounted for $53 \%(125 / 237)$ of the abnormal karyotypes; (2) chromosomes 16, 22, 15 and 21 were most frequently involved in the aneuploidies; (3) fifty-four cases $(23 \%, 54 / 237)$ with a polyploidy and $7 \%$ (16 cases) of monosomy $\mathrm{X}$ were also found and (4) individual unbalanced structural chromosome abnormality represented 4\% (10/237) of the abnormal karyotypes. 55 Russo et al. 53 applied FISH in the interphase of 855 formalin-fixed paraffin embedded miscarriage materials and the aneuploidy rate was detected at $50.3 \%$. The most frequent chromosomal abnormalities were: autosomal trisomies $(60 \%)$, polyploidies $(23.2 \%)$, and monosomy $\mathrm{X}$ (14\%). Among the autosomal trisomies, chromosome 22 was the most frequently involved (33.7\%) followed by trisomy of chromosomes $16(23.3 \%), 21(19.4 \%), 15(13.3 \%), 18$ (5.34\%), and $13(5.0 \%) .53$

Two studies 16,18 showed a higher prevalence of chromosomal abnormalities in couples with higher numbers of miscarriages. These findings corrobate previously published data, 41 that was observed in $(2 / 27)=7.4 \%$ of the couples with a history of two miscarriages, in $(3 / 23)=13 \%$ with three miscarriages and in $(4 / 23)=17.39 \%$ with four or more miscarriages. 41 On the other hand, other studies showed that the prevalence of chromosomal abnormalities does not appear to be related to the number of miscarriages. 37,42

The present findings also confirm that the chromosomal analysis in couples with RM are an important and necessary part of the etiological investigation in fetal loss. For this sense, it is essential that gynecologists/obstetricians refer to CA couples who had 2 or more recurrent miscarriages in order to confirm or exclude the contribution of chromosomal abnormalities. When a chromosomal abnormality is found in one of the partners and is precisely identified, a more exact prognosis for future pregnancies can be given. The genetic counselling with an option of prenatal diagnosis should be offered to couples with chromosomal abnormalities. 22

\section{Conclusions}

According to the data presented, it can conclude that: (1) chromosomal abnormalities, primarily balanced rearrangements are common in couples with RM; (2) the most common parental abnormalities are the balanced translocations; (3) the most frequent autosomal abnormality observed in products of conception is trisomy 16 , followed by other autossomal aneuploidies.

In summary, the cytogenetic alterations represent one of the major cause of pregnancy loss and its detection helps the couple with genetic counseling. Therefore, the value of knowledge on the prevalence of cytogenetic abnormalities in miscarriage samples is unquestionable since it permits the couple for a proper genetic counseling. In addition, researches in miscarriage material, it is appropriate the inclusion of other molecular techniques as a complementation to the conventional CA.

\section{References}

1. Royal College of Obstetricians and Gynaecologists (RCOG) (April 2011). "The investigation and treatment of couples with recurrent first-trimester and second-trimester miscarriage". Green-top Guideline No. 17. Royal College of Obstetricians and Gynaecologists (RCOG).

2. Practice Committee of American Society for Reproductive Medicine. Definitions of infertility and recurrent pregnancy loss: a committee opinion. Fertil Steril. 2013; 99 (1): 63.

3. Practice Committee of the American Society for Reproductive Medicine. Evaluation and treatment of recurrent pregnancy loss: a committee opinion. Fertil Steril. 2012; 98 (5): 1103-11.

4. Agenor A, Bhattacharya S. Infertility and miscarriage: common pathways in manifestation and management. Womens Health (Lond). 2015; 11 (4): 527-41.

5. Diejomaoh MF. Recurrent spontaneous miscarriage is still a challenging diagnostic and therapeutic quagmire. Med Princ Pract. 2015; 24 (Suppl. 1): 38-55.

6. Garrido-Gimenez C, Alijotas-Reig J. Recurrent miscarriage: causes, evaluation and management. Postgrad Med J. 2015; 91 (1073): 151-62.

7. El Hachem H, Crepaux V, May-Panloup P, Descamps P, Legendre G, Bouet PE. Recurrent pregnancy loss: current perspectives. Int J Womens Health. 2017; 9: 331-45. 
8. Shahine L, Lathi R. Recurrent pregnancy loss: evaluation and treatment. Obstet Gynecol Clin North Am. 2015; 42 (1): 117-34.

9. Costa OL, Santos EM, Netto EM. Epidemiological and obstetrics aspects in women with recurrent pregnancy losses at a public maternity in the Brazilian Northeast. Rev Bras Ginecol Obstet. 2014; 36 (11): 514-8.

10. Kacprzak M, Chrzanowska M, Skoczylas B, Moczulska H, Borowiec M, Sieroszewski P. Genetic causes of recurrent miscarriages. Ginekol Pol. 2016; 87 (10): 722-6.

11. Teixeira ACZ, Oliveira ARCP de, Pereira TM, Jesus NA de, Rodrigues MG, Salvador R, Agostinho MA de B, Rodini ESO. Estudo citogenético de abortos espontâneos. Arq Ciênc Saúde. 2009; 16 (2): 59-61.

12. Rolnik DL, Carvalho MHB, Catelani ALPM, Pinto APAR, Lira JBG, Kusagari NK, Belline P, Chauffaille M de L. Análise citogenética em material de abortamento espontâneo. Rev Assoc Med Bras. 2010; 56 (6): 681-3.

13. van den Berg MM, van Maarle MC, van Wely M, Goddijn M. Genetics of early miscarriage. Biochim Biophys Acta. 2012; 1822 (12): 1951-9.

14. Shi X, Xie X, Jia Y, Li S. Maternal genetic polymorphisms and unexplained recurrent miscarriage: a systematic review and meta-analysis. Clin Genet. 2017; 91 (2): 265-84

15. Tur-Torres MH, Garrido-Gimenez C, Alijotas-Reig J. Genetics of recurrent miscarriage and fetal loss. Best Pract Res Clin Obstet Gynaecol. 2017; 42: 11-25.

16. Ghazaey S, Keify F, Mirzaei F, Maleki M, Tootian S, Ahadian M, Abbaszadegan MR. Chromosomal analysis of couples with repeated spontaneous abortions in northeastern iran. Int J Fertil Steril. 2015; 9 (1): 47-54.

17. Ozawa N, Maruyama T, Nagashima T, Ono M, Arase T, Ishimoto $\mathrm{H}$, Yoshimura Y. Pregnancy outcomes of reciprocal translocation carriers who have a history of repeated pregnancy loss. Fertil Steril. 2008; 90 (4): 1301-4.

18. Kiss A, Rosa RF, Dibi RP, Zen PR, Pfeil JN, Graziadio C, Paskulin GA. Chromosomal abnormalities in couples with history of recurrent abortion. Rev Bras Ginecol Obstet. 2009; 31 (2): 68-74.

19. Pal S, Ma SO, Norhasimah M, Suhaida MA, Siti Mariam I, Ankathil R, Zilfalil BA. Chromosomal abnormalities and reproductive outcome in Malaysian couples with miscarriages. Singapore Med J. 2009; 50 (10): 1008-12.

20. Dutta UR, Rajitha P, Pidugu VK, Dalal AB. Cytogenetic abnormalities in 1162 couples with recurrent miscarriages in southern region of India: report and review. J Assist Reprod Genet. 2011; 28 (2): 145-9.

21. Niroumanesh S, Mehdipour P, Farajpour A, Darvish S. A cytogenetic study of couples with repeated spontaneous abortions. Ann Saudi Med. 2011; 31 (1): 77-9.

22. Gada Saxena S, Desai K, Shewale L, Ranjan P, Saranath D. Chromosomal aberrations in 2000 couples of Indian ethnicity with reproductive failure. Reprod Biomed Online. 2012; 25 (2): 209-18.

23. Gonçalves RO, Santos WV, Sarno M, Cerqueira BA, Gonçalves MS, Costa OL. Chromosomal abnormalities in couples with recurrent first trimester abortions. Rev Bras Ginecol Obstet. 2014; 36 (3): 113-7.
24. Karatas A, Eroz R, Albayrak M, Ozlu T, Cakmak B, Keskin F. Evaluation of chromosomal abnormalities and common trombophilic mutations in cases with recurrent miscarriage. Afr Health Sci. 2014; 14 (1): 216-22.

25. Fan HT, Zhang M, Zhan P, Yang X, Tian WJ, Li RW. Structural chromosomal abnormalities in couples in cases of recurrent spontaneous abortions in Jilin Province, China. Genet Mol Res. 2016; 15(1).

26. Sudhir N, Kaur T, Beri A, Kaur A. Cytogenetic analysis in couples with recurrent miscarriages: a retrospective study from Punjab, north India. J Genet. 2016; 95 (4): 887-94.

27. López AGA, Huerta SB, Gálvan RH, Posadas RA, del Ángel AG, González PG. Diagnóstico citogenético en aborto espontáneo del primer trimestre. Ginecol Obstet Mex. 2011; 79 (12): 779-84

28. Salazar A, Álamos C, Arriagada M, Selman E. Estudio Citogenético en 677 casos de aborto espontáneo. Revista Anacem. 2011; 5 (2): 74-7.

29. Boué J, Boué A, Lazar P. Retrospective and prospective epidemiological studies of 1500 karyotyped spontaneous human abortions. 1975. Birth Defects Res A Clin Mol Teratol. 2013; 97 (7): 471-86.

30. Bastos R, Ramalho C, Dória S. [Prevalence of chromosomal abnormalities in spontaneous abortions or fetal deaths]. Acta Med Port. 2014; 27 (1): 42-8.

31. Serrano F, Lima ML. Recurrent miscarriage: psychological and relational consequences for couples. Psychol Psychother. 2006; 79 (Pt 4): 585-94.

32. Mevorach-Zussman N, Bolotin A, Shalev H, Bilenko N, Mazor M, Bashiri A. Anxiety and deterioration of quality of life factors associated with recurrent miscarriage in an observational study. J Perinat Med. 2012; 40 (5): 495-501.

33. Legendre G, Gicquel M, Lejeune V, Iraola E, Deffieux X, Séjourné N, Bydlowski S, Gillard P, Sentilhes L, Descamps P. [Psychology and pregnancy loss]. J Gynecol Obstet Biol Reprod (Paris). 2014; 43 (10): 908-17.

34. Celep F, Karagüzel A, Ozeren M, Bozkaya H. The frequency of chromosomal abnormalities in patients with reproductive failure. Eur J Obstet Gynecol Reprod Biol. 2006; 127 (1): 106-9.

35. Azim M, Khan AH, Khilji ZL, Pal JA, Khurshid M. Chromosomal abnormalities as a cause of recurrent abortions: a hospital experience. J Pak Med Assoc. 2003; 53 (3): 117-9.

36. Rao L, Murthy K, Babu A, Venkata P, Deenadayal M, Singh L. Chromosome inversions and a novel chromosome insertion associated with recurrent miscarriages in South India. Arch Gynecol Obstet. 2005; 272 (4): 273-7.

37. Elghezal H, Hidar S, Mougou S, Khairi H, Saâd A. Prevalence of chromosomal abnormalities in couples with recurrent miscarriage. Fertil Steril. 2007; 88 (3): 721-3.

38. Yuce H, Tekedereli I, Elyas H. Cytogenetic results of recurrent spontaneous abortions in Turkey. Med Sci Monit. 2007; 13 (6): CR286-89.

39. Meza-Espinoza JP, Anguiano LO, Rivera H. Chromosomal abnormalities in couples with reproductive disorders. Gynecol Obstet Invest. 2008; 66 (4): 237-40. 
40. Goud TM, Mohammed Al Harassi S, Khalfan Al Salmani K, Mohammed Al Busaidy S, Rajab A. Cytogenetic studies in couples with recurrent miscarriage in the Sultanate of Oman. Reprod Biomed Online. 2009; 18 (3): 424-9.

41. El-Dahtory FA. Chromosomal abnormalities as a cause of recurrent abortions in Egypt. Indian J Hum Genet. 2011; 17 (2): $82-4$.

42. Kochhar PK, Ghosh P. Reproductive outcome of couples with recurrent miscarriage and balanced chromosomal abnormalities. J Obstet Gynaecol Res. 2013; 39 (1): 11320 .

43. Sheth FJ, Liehr T, Kumari P, Akinde R, Sheth HJ, Sheth JJ. Chromosomal abnormalities in couples with repeated fetal loss: An Indian retrospective study. Indian J Hum Genet. 2013; 19 (4): 415-22

44. Alaraji SMH. Chromosomal abnormalities associated with recurrent spontaneous abortions in Iraqi women. Med J Babylon. 2014; 7: 2.

45. Flynn H, Yan J, Saravelos SH, Li TC. Comparison of reproductive outcome, including the pattern of loss, between couples with chromosomal abnormalities and those with unexplained repeated miscarriages. J Obstet Gynaecol Res. 2014; 40 (1): 109-16

46. Turki RF, Banni HA, Assidim M, Al-Qahtani MH, Abduljabbar HS, Jamel HS, Rouzi AA, Abuzenadah AM. Analysis of chromosomal and genetic disorders in patients with recurrent miscarriages in Saudi Arabia. BMC Genomics. 2014; 15 (Suppl. 2): P73.

47. Dong Y, Du RC, Jiang YT, Wu J, Li LL, Liu RZ. Impact of chromosomal translocations on male infertility, semen quality, testicular volume and reproductive hormone levels J Int Med Res. 2012; 40 (6): 2274-83.

48. Flannigan R, Schlegel PN. Genetic diagnostics of male infertility in clinical practice. Best Pract Res Clin Obstet Gynaecol. 2017; 44: 26-37.

49. Minocherhomji S, Athalye AS, Madon PF, Kulkarni D, Uttamchandani SA, Parikh FR. A case-control study identifying chromosomal polymorphic variations as forms of epigenetic alterations associated with the infertility pheno- type. Fertil Steril. 2009; 92 (1): 88-95.

50. Mierla D, Stoian V. Chromosomal polymorphisms involved in reproductive failure in the romanian population. Balkan $\mathrm{J}$ Med Genet. 2012; 15 (2): 23-8.

51. Morales R, Lledó B, Ortiz JA, Ten J, Llácer J, Bernabeu R. Chromosomal polymorphic variants increase aneuploidies in male gametes and embryos. Syst Biol Reprod Med. 2016; 62 (5): 317-24

52. Jia CW, Wang L, Lan YL, Song R, Zhou LY, Yu L, Yang Y, Liang Y, Li Y, Ma YM, Wang SY. Aneuploidy in Early Miscarriage and its Related Factors. Chin Med J (Engl). 2015; 128 (20): 2772-6

53. Russo R, Sessa AM, Fumo R, Gaeta S. Chromosomal anomalies in early spontaneous abortions: interphase FISH analysis on 855 FFPE first trimester abortions. Prenat Diagn. 2016; 36 (2): 186-91

54. Kim JW, Lyu SW, Sung SR, Park JE, Cha DH, Yoon TK, Ko JJ, Shim SH. Molecular analysis of miscarriage products using multiplex ligation-dependent probe amplification (MLPA): alternative to conventional karyotype analysis. Arch Gynecol Obstet. 2015; 291 (2): 347-54

55. Jenderny J. Chromosome aberrations in a large series of spontaneous miscarriages in the German population and review of the literature. Mol Cytogenet. 2014; 7: 38 .

56. Teles TM, Paula CM, Ramos MG, Costa HB, Andrade CR, Coxir SA, Penna ML. Frequency of Chromosomal Abnormalities in Products of Conception. Rev Bras Ginecol Obstet. 2017; 39 (3): 110-4.

57. Shen J, Wu W, Gao C, Ochin H, Qu D, Xie J, Gao L, Zhou Y, Cui Y, Liu J. Chromosomal copy number analysis on chorionic villus samples from early spontaneous miscarriages by high throughput genetic technology. Mol Cytogenet. 2016; 9: 7.

58. Hardy K, Hardy PJ. 1(st) trimester miscarriage: four decades of study. Transl Pediatr. 2015; 4 (2): 189-200.

59. Yakut S, Toru HS, Çetin Z, Özel D, Şimşek M, Mendilcioğlu İ, Lüleci G. Chromosome abnormalities identified in 457 spontaneous abortions and their histopathological findings. Turk Patoloji Derg. 2015; 31 (2): 111-8.

Received on October 15, 2017

Final version presented on April 23, 2018

Approved on May 04, 2018 